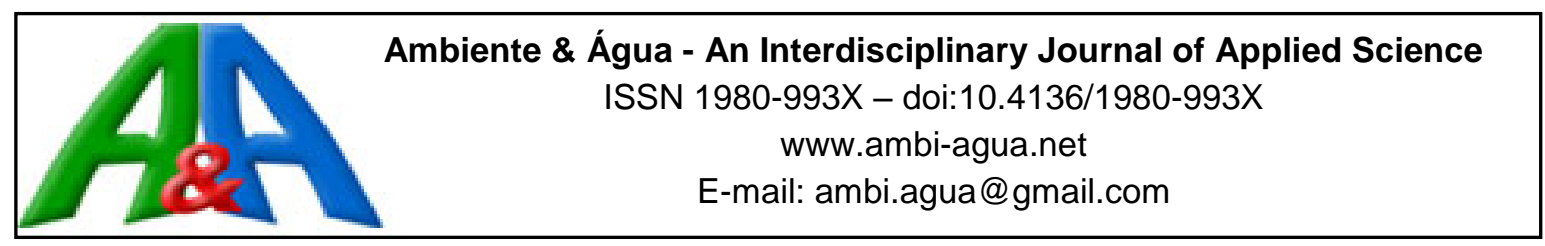

\title{
Potential for reuse of effluent from fish-processing industries
}

\author{
doi:10.4136/ambi-agua.2045 \\ Received: 16 Nov. 2016; Accepted: 13 Jun. 2017 \\ Luana Morena Rodrigues Vitor Dias Ferraciolli'; \\ Danielle de Bem Luiz ${ }^{2}$; Liliana Pena Naval ${ }^{{ }^{*}}$ \\ ${ }^{1}$ Universidade Federal do Tocantins (UFT), Palmas, TO, Brasil \\ Departamento Engenharia Ambiental \\ ${ }^{2}$ Empresa Brasileira de Pesquisa Agropecuária (Embrapa) Pesca e Aquicultura, Palmas, TO, Brasil \\ Departamento de Pesca e Aquicultura \\ *Autor correspondente e-mail: liliana@uft.edu.br, \\ luanamorena1990@gmail.com, danielle.luiz@embrapa.br
}

\begin{abstract}
The most common problems in the fish processing industry relate to high water consumption and the generation of effluents with concentrated organic loads. Given that reuse can represent an alternative for sustainable development, this study sought to assess the potential for recycling effluents produced in a fish-processing plant. In order to do so, the final industrial effluent was analyzed using the American Public Health Association (APHA) standard effluent-analysis method (2005). In addition, the study assessed treatments which produce effluents meeting the requirements prescribed by different countries' regulations for reuse and recycling. The results found that effluents with smaller organic loads, such as those from health barriers and monoblock washing, can be treated in order to remove nutrients and solids so that they can be subsequently reused. For effluents produced by the washing and gutting cylinders, it is recommended that large fragments of solid waste be removed beforehand. Effluents can in this way attain a quality compatible with industrial reuse. This study further highlights the possibility of treating effluents so as comply with drinking water standards. This would potentially allow them to be used within the actual fish-processing procedure; in such a case, a revision of standards and measures for controlling use should be considered to prevent microbiological damage to products and risks to handlers and final consumers.
\end{abstract}

Keywords: effluent treatment, fish processing, reuse, sustainability.

\section{Potencial de reuso de efluente de indústrias de processamento de pescado}

\section{RESUMO}

Os problemas mais comuns em indústrias processadoras de pescado estão relacionados ao alto consumo de água e à geração de efluente contendo cargas orgânicas concentradas. Sendo o reuso uma alternativa para o desenvolvimento sustentável na indústria, este estudo teve como objetivo avaliar o potencial de reciclo de efluentes gerados em uma indústria processadora de pescado. Para isto, realizou-se a caracterização do efluente industrial final empregando métodos padrões para a análise de esgoto da American Public Health Association, APHA (2005). Em adição, foram avaliados tratamentos empregados capazes de produzir efluentes que atendem 
aos requisitos preconizados por regulamentos de diferentes países para o reuso e reciclo. Os resultados obtidos demonstraram que os efluentes com menores cargas orgânicas, como os da barreira sanitária e lavagem de monoblocos, podem ser submetidos a tratamentos que priorizem a remoção de nutrientes e sólidos para posterior reciclo. Para o efluente proveniente de etapas do cilindro de lavagem e da evisceração, recomenda-se previamente a remoção dos resíduos sólidos grosseiros, de maneira que o efluente quando submetido a tratamento possa alcançar qualidade para o reuso industrial. Destaca-se ainda a possibilidade de tratar esses efluentes de modo que atendam as características de água potável, o que suscita a possibilidade de uso no processamento do pescado propriamente dito, considerando-se a necessidade de revisão das normas e de medidas de controle de uso de forma a impedir danos microbiológicos ao produto e riscos ao manipulador e ao consumidor final.

Palavras-chave: processamento de pescado, reuso, sustentabilidade, tratamento de efluente.

\section{INTRODUCTION}

Brazil has one of the largest economies in the world, with a gross domestic product (GDP) of more than two trillion USD in 2013, according to a report by the Organisation for Economic Co-operation and Development (OECD, 2013). Of note is the growth of the aquaculture sector, the expansion of which is attributed to the emergence of public policies to encourage the production and consumption of fish. According to data from the Brazilian Institute of Geography and Statistics (IBGE) (IBGE, 2014), the total production of Brazilian fish farming was 474.33 thousand tons in 2014, an increase of $20.9 \%$ over the previous year.

The use of water is necessary for the transformation of the raw material into products destined to the consumer. Since the total volume of effluent is directly related to the amount of water used, reuse and recycling should be considered as possibilities for minimizing water use, and the consequent generation of effluents. However, those alternatives have not been implemented in most food industries, given the lack of information available on the production, treatment and use of the effluent. It is also worth noting that, in addition to the volume generated, it is estimated that between $40 \%$ and $70 \%$ of the product is transformed into organic waste (Herpandi et al., 2011, Silva et al., 2014), the disposition of which has no protocol, contributing a high organic load to the generated effluents, and increasing the costs of treatment and/or polluting the receiving water bodies.

In Brazil's case, there still exists the need to create more specific and updated regulations that regulate the practice of reuse. In food industries, care must be taken regarding the risks related to product integrity, the environment, and the health of manipulators and consumers; therefore, Brazilian legislation allows only the use of drinking water from natural sources in these industries (Brasil, 1999).

The need to minimize the health and environmental risks associated with the application of water/effluent reuse has led an increasing number of countries to develop guidelines and regulations for the safe use of treated effluents (Bixio and Wintgens, 2006).

There are several international guidelines that address the possibilities of reuse. The World Health Organization (WHO) guidelines (WHO, 2006) apply Hazard Analysis and Critical Points (HACCP) and a risk-management framework in the management of reuse. Some countries take the lead in terms of industrial reuse, such as the United States of America. In that country, despite not adopting federal-reuse regulations, the Environmental Protection Agency (EPA) has created suggested guidelines for the development of reuse programs based on the experiences of several US states (USEPA, 2004).

Europe also stands out, although there are no regulations at a EU level. Several Member States and autonomous regions have produced their own legislative frameworks, regulations or guidelines for water-reuse applications (Alcalde-Sanz and Gawlik, 2014). Of the EU members, 
Greece and Spain stand out because they have regulations that apply to a large number of uses, including a precise description of the quality requirements for each application. The Greek standards apply stringent limits for some industrial uses, and unrestricted irrigation, aquifer recharge and urban uses, based on FAO's (Food and Agriculture Organization of the United Nations) recommendations on irrigation water quality (Ayers and Westcot, 1985).

Brazil's first regulation relating to the concentration limits of pollutants in effluents for reuse was the Technical Standard NBR 13.969 in 1997 (ABNT, 1997). This regulatory norm also defines the classes of water of reuse, and the respective quality standards. In 2005, modalities, guidelines and general criteria for direct reuse of non-potable water were established in Brazil by Resolution $n^{\circ} 54$ of November 28, 2005 / promulgated by CNRH (National Council of Water Resources) (CNRH, 2006). The modalities outlined by the Resolution were reuse for urban purposes, reuse for agricultural and forestry purposes, reuse for environmental purposes, reuse for industrial purposes and reuse in aquaculture.

The standards, procedures and legislation applicable to reuse are in general defined, creating parameters and reference values for uses in agriculture, aquifer recharge, and urban and industrial scenarios. However, in order to guarantee the safety of the products of the food industry, a sector that restricts the reuse of water in its processes, Brazil enacted Resolution $\mathrm{n}^{\circ}$ 01/80 (Conmetro, 1980), which in turn created the Codex Alimentarius Committee of Brazil.

For meat processing industries, the Department of Animal Products Inspection (DIPOA), linked to the Department of Agricultural and Livestock Defense (SDA) of the Ministry of Agriculture, Livestock and Supply (MAPA), is responsible for inspecting products. In relation to the quality of water used in the processing of fish products, the following regulations are applied: Presidential Decree 30.691/1952 created the Regulation of the Industrial and Sanitary Inspection of Products of Animal Origin (RIISPOA) (Brasil, 1952), which prohibits the reuse of wastewater and allows the connection of the water network and the pre-chillers for the conduction of other inedible waste, ensuring technological and hygienic-sanitary adequacy. The decree also creates water quality standards to be used in animal food industries. Portaria SVS/MS 326/1997 of the Ministry of Health (Brazil, 1997) provides for the use of non-potable water as described in its Production Hygiene Requirements.

Despite Brazilian decrees that regulate the reuse of treated water in the preparation, handling and packaging of food for various purposes, the process is mainly impeded by the risk of contamination, concern about consumer acceptance, and the lack of specific regulations. Due to a lack of relating studies or experience, these could not be based upon knowledge gleaned through scientific analysis, which is why this practice is currently not recommended in Brazil (Matsumura and Mierzwa, 2008).

Therefore, studies should be carried out to guide the implementation of the practice, given the importance of the associated environmental, social and economic factors. Since a large volume of effluent is generated by the fish processing industry, this study aimed to evaluate its potential reuse or recycling, and to explore scenarios for its reuse in industrial processes.

\section{METHODOLOGY}

\subsection{Description of the study unit}

The study was conducted in a fish warehouse in the northern region of Brazil that produces fresh gutted fish of various species. The warehouse has processing capacity of 12 tonnes per day, and as shown in Figure 1, it is subdivided into three areas: dirty area (for slaughter and initial carcass washing), clean area (for evisceration, cleaning and packaging) and administrative area.

For processing, the fish is sent to the dirty area and the first cleaning is carried out in a washing cylinder, where effluent is generated (Point A, Figure 1). The carcass then moves to 
the clean area, for abdominal incision, evisceration and cleaning. The fish is then placed in monoblocs for weighing and the addition of flaked ice. The fish is ready for shipping after its temperature is stabilized.

After fish processing, the monoblocs, the floors, the equipment and the ice maker are cleaned. Each of these stages generates effluents. The effluent of Point B (Figure 1) is from health barriers (process employee hygiene) and washing of monoblocs, floors and equipments.

\subsection{Effluent characterization}

For the qualitative characterization of all effluents of Points A and B (data not shown) and the final effluent of the process (Point C, Figure 1), eleven samples were collected and physical, chemical and microbiological parameters were analyzed using the standard guidelines for water and sewage analysis developed by APHA (2005). The parameters characterized were: thermotolerant coliforms, biochemical oxygen demand (BOD), $\mathrm{pH}$, total suspended solids (TSS) and turbidity.

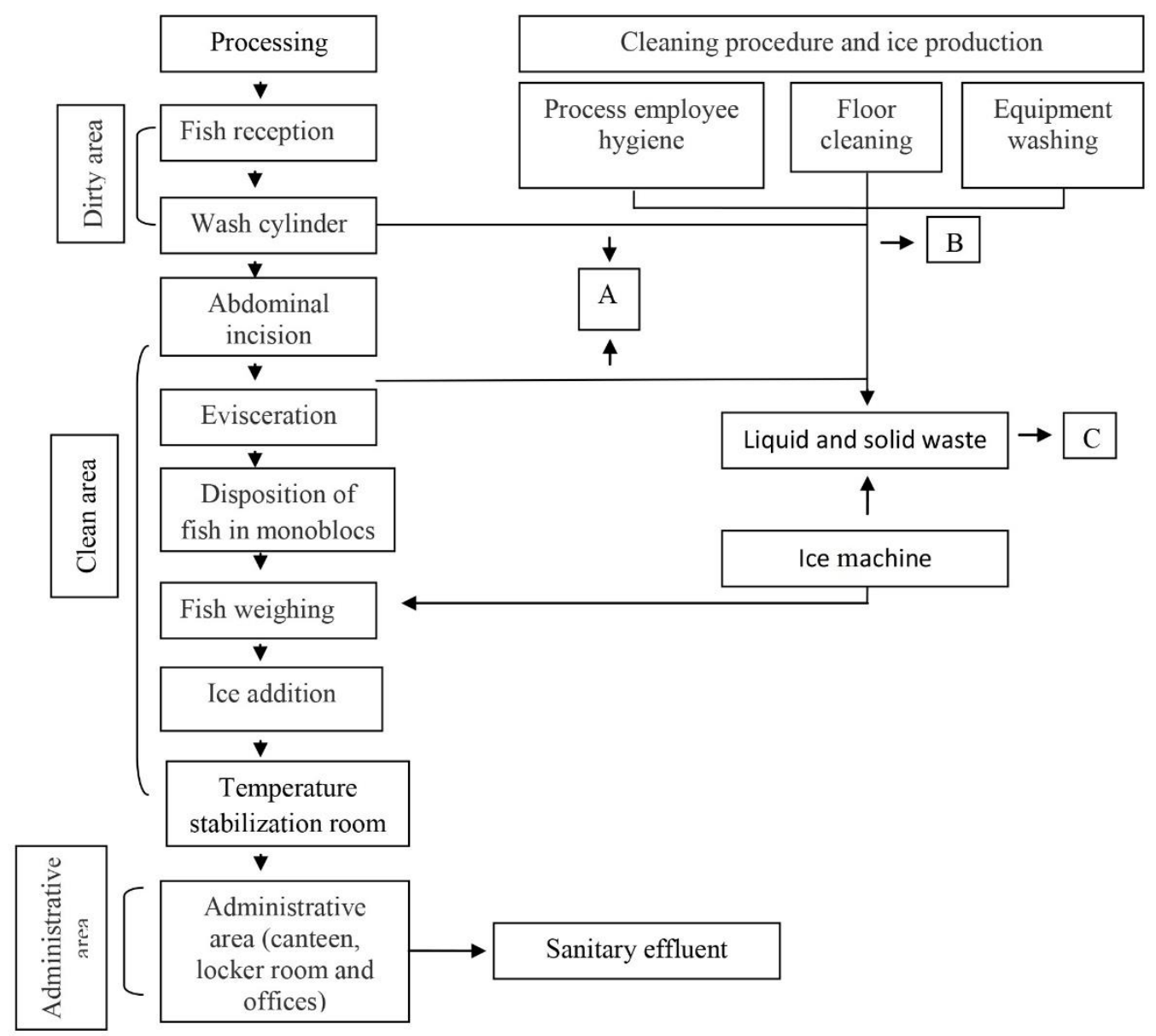

Figure 1. Flow chart showing the fish processing, cleaning procedure and ice production in the plant studied.

\subsection{Evaluation of the reuse or recycling potential of effluent}

The results obtained in the characterization were compared with the quality standards for reuse and/or recycling enacted by the following regulations: the Brazilian norm NBR 13969: 1997 (ABNT, 1997), European regulations (from Spain, by Royal Decree 1620, Spain, 2007) and Greece, by Ministerial Decree (Greece, 2011) (USEPA, 2012) (Table 1). These regulations, guidelines and standards specify the concentrations allowed for industrial reuse. 
Table 1. Quality requirements for reuse and/or recycling as per regulations and standards for industrial reuse of effluent.

\begin{tabular}{|c|c|c|}
\hline Concentration limits & Application & Country \\
\hline $\begin{array}{l}\text { Faecal coliform }<200 \mathrm{NPM} / 100 \mathrm{~mL} \text {; } \\
\text { pH between } 6 \text { and } 8 \text {; Turbidity }<5 \mathrm{NTU} \\
* \text { Free residual chlorine between } 0.5 \text { and } \\
1.5 \mathrm{mg} / \mathrm{L}\end{array}$ & $\begin{array}{l}\text { Class } 1 \text { water: used for car washing, } \\
\text { direct contact of users with water, } \\
\text { aerosol aspiration }\end{array}$ & \\
\hline $\begin{array}{l}\text { Faecal coliform }<500 \mathrm{NPM} / 100 \mathrm{~mL} \text {; } \\
\text { Turbidity }<5 \mathrm{NTU} \\
\text { *Free residual chlorine }>0.5 \mathrm{mg} / \mathrm{L}\end{array}$ & $\begin{array}{l}\text { Class } 2 \text { water: used for washing floors } \\
\text { and pavements, watering gardens, } \\
\text { maintaining lakes and canals for } \\
\text { landscape purposes, except fountains }\end{array}$ & Brazil \\
\hline Faecal coliform < 500 NPM/100mL; & Class 3 water: used for flushing toilets & \\
\hline $\begin{array}{l}\text { Faecal coliform < } 500 \text { NPM } / 100 \mathrm{~mL} \text {; } \\
\text { Turbidity < } 10 \mathrm{NTU} \\
\text { *Dissolved Oxygen }>2 \mathrm{mg} / \mathrm{L} \text {; }\end{array}$ & $\begin{array}{l}\text { Class } 4 \text { water: reuse in orchards, cereal, } \\
\text { fodder, cattle pastures and other crops } \\
\text { through surface drainage or specific } \\
\text { irrigation systems }\end{array}$ & \\
\hline
\end{tabular}

TSS: $35 \mathrm{mg} / \mathrm{L}$; Turbidity: $15 \mathrm{NTU}$

*Escherichia coli: $10^{4}$ ufc/100 mL;

*Legionella spp:100 ufc/L;

Cleaning process, but not for the food industry

TSS: $35 \mathrm{mg} / \mathrm{L}$;

*Escherichia coli: $10^{3}$ ufc/100 mL;

*Nematode Eggs: 1 eggs/10 mL;

Processing and washing water in the food industry

Spain

*Legionella spp: $100 \mathrm{ufc/L}$

TSS: 5 mg/L; Turbidity: 1 NTU

*Escherichia coli: 0 ufc/100mL;

*Nematode Eggs: 1 eggs/10 mL;

Cooling towers and evaporative condensers

$\mathrm{BOD} \leq 30 \mathrm{mg} / \mathrm{L} ;$

Thermotolerant coliforms $\leq 200 / 100 \mathrm{~mL}$

$\mathrm{pH}$ between 6 and 9; TSS $\leq 30 \mathrm{mg} / \mathrm{L}$;

Cooling without recirculation

*Minimum residual chlorine $1 \mathrm{mg} / \mathrm{L}$

USA

$\mathrm{BOD} \leq 30 \mathrm{mg} / \mathrm{L}$;

Thermotolerant coliforms $\leq 200 / 100 \mathrm{~mL}$ $\mathrm{pH}$ between 6 and 9; TSS $\leq 30 \mathrm{mg} / \mathrm{L}$;

*Minimum residual chlorine $1 \mathrm{mg} / \mathrm{L}$

*Escherichia coli $\leq 200 \mathrm{ufc} / 100 \mathrm{~mL}$ (average)

Cooling water

pH: 6-8.5 BOD: $\leq 10 \mathrm{mg} / \mathrm{L}$ (in $80 \%$ of

samples);

TSS: $\leq 10 \mathrm{mg} / \mathrm{L}$ (in $80 \%$ of samples);

Turbidity $\leq 2$ NTU

*Escherichia coli: $\leq 5 \mathrm{ufc} / 100 \mathrm{ml}(80 \%$ of

Use of single reticulated cooling water,

Greece samples), $\leq 50$ (in $95 \%$ of samples).

*Parameters not determined in this study.

\section{RESULTS AND DISCUSSION}

In general, effluents from fish processing have varied characteristics, depending on the particular processes that produce them, the type of fish (Alexandre et al., 2011) and the size, seasonality and productivity of each industrial unit. For this study, the characterization of the 
effluent generated in a fish processing industry was carried out to evaluate its reuse or recycling potential (Table 2). From the parameters evaluated, some results show a discrepancy in the concentrations found, as expected, for BOD, $\mathrm{pH}$ and TSS, when compared to the results of other studies (Table 2).

Table 2. Characterization of effluents from fish processing units.

\begin{tabular}{|c|c|c|c|c|c|c|}
\hline Final Product & $\begin{array}{c}\text { Colif. } \\
\text { (NMP/100 mL) }\end{array}$ & $\mathrm{BOD}_{5}(\mathrm{mg} / \mathrm{L})$ & $\mathrm{pH}$ & TSS (mg/L) & $\begin{array}{l}\text { Turbidity } \\
\text { (NTU) }\end{array}$ & Ref. \\
\hline Gutted fresh fish & $1-1000$ & 487- 1350.7 & $5.5-8.5$ & $60-945$ & $34.7-231$ & $*$ \\
\hline $\begin{array}{l}\text { Fresh gutted } \\
\text { squid and } \\
\text { scallops }\end{array}$ & - & 3000 & $7.5-8.3$ & 635 & - & $\begin{array}{l}\text { Muthukumaran } \\
\text { and Baskaran } \\
\text { (2013) }\end{array}$ \\
\hline $\begin{array}{l}\text { Frozen tilapia } \\
\text { fillets }\end{array}$ & - & - & 9.4 & - & - & $\begin{array}{l}\text { Lima et al. } \\
\text { (2011) }\end{array}$ \\
\hline Canned fish & - & 2860 & 6.7 & - & - & $\begin{array}{l}\text { Valent et al. } \\
\text { (2010) }\end{array}$ \\
\hline Canned fish & - & $463-4569$ & $6.1-7.1$ & $324-3150$ & - & $\begin{array}{l}\text { Cristóvão et al. } \\
\text { (2015) }\end{array}$ \\
\hline Canned tuna & - & - & $5.8-6.2$ & $51-91$ & - & $\begin{array}{l}\text { Jemli et al. } \\
\text { (2015) }\end{array}$ \\
\hline
\end{tabular}

Note: Colif. $=$ thermo-tolerant coliforms; $\mathrm{BOD}=$ Biochemical Oxygen Demand; $\mathrm{pH}=$ potencial hydrogen; $\mathrm{TSS}=$ Total Suspended Solids; Ref. = Reference. * Data obtained in this study.

Source: Muthukumaran and Baskaran (2013); Lima et al. (2011); Valent et al. (2010); Cristóvão et al. (2015); Jemli et al. (2015).

While it is uncommon to do so, this study evaluated thermo-tolerant coliforms in order to assess the sanitary quality of the effluent, with a view to reuse. The results for the final industrial effluent were $1000 \mathrm{NMP} / 100 \mathrm{~mL}$ (Table 2).

In this study (Table 2), the $\mathrm{BOD}_{5}$ concentration varied from 487.5 to $1350.7 \mathrm{mg} / \mathrm{L}$, differing from the results obtained by Muthukumaran and Baskaran (2013), which evaluated the final effluent from the processing of squid and scallops, and found concentrations around $3000 \mathrm{mg} / \mathrm{L}$; and for Valent et al. (2010), who studied the effluent of a fish canning industry, finding a BOD equal to $2860 \mathrm{mg} / \mathrm{L}$ (Table 2).

The concentration of suspended solids ranged from $60-945 \mathrm{mg} / \mathrm{L}$ in the studied effluent (Table 2). The results of Muthukumaran and Baskaran (2013) were $635 \mathrm{mg} / \mathrm{L}$ of TSS (Table 2), which also produces fresh, eviscerated seafood, but the products processed are squid and scallops. In the fish-preservation industry, concentrations of this parameter may be higher, such as those found in effluent from the sardine-canning industry, which presented concentrations ranging from 120 to $4,980 \mathrm{mg} / \mathrm{L}$ of TSS (Achour et al., 2000). For the tuna effluent, the concentration found was up to $6,100 \mathrm{mg} / \mathrm{L}$ (Achour et al., 2000).

For turbidity, this study obtained between 34.7 and 231 NTU (Table 2). This parameter was not explored in other studies, but was considered important because it is directly associated with suspended solids, which tends to have high concentrations in the effluent of fish processing industries (Artiga et al., 2008; Cristóvão et al., 2015) due to the high levels of proteins and lipids.

The $\mathrm{pH}$ was between 5.5 and 8.5 (Table 2). This resembled the effluents characterized by Muthukumaran and Baskaran (2013) (Table 2) for fresh gutted squid and scallops processing 
industry, but was far from the value found by Lima et al. (2011), 9.4, who studied effluents from the processing of frozen tilapia fillets (Table 2).

The characterization confirmed that fish processing effluent can vary widely depending on different factors, and it must be noted that fish processing may involve different steps that involve the degree of manipulation of the product, classification, removal of surface impurities, scaling, washing, head removal, evisceration, cutting of fins, fillet cutting, bone/pimple separation, drying, salting, freezing or cooling, packaging, labeling, distribution, among others (Ghaly et al., 2013). In the case of canning industries, there are also steps such as brining, canning, cooking, adding oil or sauce, canning, can washing, autoclaving and washing for cooling. In addition to the wash waters of the fish, there is water from floor washing and from equipment, which is included in the industrial effluent.

In general, it is important to characterize the effluent in order to know the quality of the sewage generated, and whether or not it complies with regulations for discharge into bodies of water, or for reuse and/or recycling. In case of non-compliance with the minimum requirements prescribed by regulations, ordinances and the like, the effluent must be treated in order to achieve at least the minimum requirements.

Therefore, in order to evaluate the potential for reuse of effluents from fish processing, the effluent characteristics of the studied industry were compared with existing regulations for industrial reuse (Table 3). When the quality of these effluents did not achieve the regulation requirements, treatments are proposed to achieve the required quality for reuse and recycle (Table 3).

The effluent characterization found that the coliform parameter presented a microbiological risk because it exceeds the concentration recommended by the Brazilian Association of Technical Norms (ABNT, 2007), which recommends $<200 \mathrm{NPM} / 100 \mathrm{~mL}$ (Table 3), and by North American regulation (USEPA, 2012), which suggests $<200 \mathrm{NPM} / 100$ $\mathrm{mL}$ (Table 3). Studies indicate that this bacteria must be eliminated if the effluent were to be reused due to the health risk presented (Mavrov and Bélières, 2000).

Although the characteristics of the effluent studied do not meet the requirements of the ABNT and EPA regulations, effluents can be treated to enable reuse. Mavrov and Bélières (2000) showed that low-contaminated effluents pretreated with membrane filtration, UV disinfection and nanofiltration followed by reverse osmosis in a food processing industry in Germany achieved the quality of drinking water, and its reuse was therefore permitted.

The BOD concentration found was between 487.5-1,350.7 mg/L, characteristic of effluents from the fish-processing industry (Cristóvão et al., 2015), but did not meet any of the regulations that adopt BOD as a quality parameter; for EPA: $\leq 30 \mathrm{mg} / \mathrm{L}$, USEPA (2012); and for the Greek regulation: $\leq 10 \mathrm{mg} / \mathrm{L}$ (80\% of samples), Greece (2011). However, adopting the treatment proposal of Queiroz et al. (2013), the effluent presented a potential for reuse in industrial processes (Table 3) when treated with microalgae, coagulation/flocculation, sedimentation and microfiltration.

The effluent's TSSconcentration was between $60-945 \mathrm{mg} / \mathrm{L}$; this result exceeds the concentrations recommended by the EPA (USEPA, 2012) for applications such as cooling water; it exceeds the concentration recommended by Spain (Spain, 2007) for use of water in industrial cleaning, and it is above the concentration recommended by Greek regulation (Greece, 2011) for use in industrial processes.

The need to remove TSS from the effluent is therefore evident. To accomplish this, Cristóvão et al. (2014) subjected the final effluent to sedimentation, followed by chemical coagulation and flocculation, which removed approximately $86 \%$ of the TSS (Table 3). When the effluent was submitted to activated sludge treatment followed by osmosis, the removal percentage achieved was $98.4 \%$ (Table 3 ). The removal of $98.4 \%$ of TSS would achieve compliance with EPA standards (USEPA, 2012), which require a concentration of $\leq 30 \mathrm{mg} / \mathrm{L}$. 
It would also comply with Spanish regulation (Spain, 2007), which allows up to $35 \mathrm{mg} / \mathrm{L}$ of TSS for use in cleaning in the food industry (Table 3). The Greek regulation (Greece, 2011) is more restrictive for TSSs $(\leq 10 \mathrm{mg} / \mathrm{L})$, but would allow reuse as disposable reticulated cooling water, cooling water for boilers and water for use in processes that do not come into contact with food (Table 3).

Table 3. Potential industrial reuse of effluents produced by the fish processing plant and treatment proposed to comply with regulations and standards.

\begin{tabular}{|c|c|c|c|c|}
\hline Parameter & $\begin{array}{c}\text { Final } \\
\text { Effluent }\end{array}$ & Standard & Treatment & Standards \\
\hline \multirow{3}{*}{ BOD } & \multirow{3}{*}{858} & \multirow{3}{*}{$\begin{array}{l}\leq 30 \mathrm{mg} / \mathrm{L} \text { USEPA }(2012) \\
\leq 10 \mathrm{mg} / \mathrm{L}(80 \% \text { of } \\
\text { samples) Greece }(2011)\end{array}$} & $\begin{array}{l}\text { Biological } \\
\text { (activated sludge) }^{1} \\
\text { (use of microalgae) }^{3}\end{array}$ & \multirow{3}{*}{$\begin{array}{l}\text { Decree } 1620 \text { Spain } \\
(2007), \text { USEPA } \\
(2012), \text { Greece }(2011) \\
\text { and Brazil (ABNT, } \\
\text { 1997). }\end{array}$} \\
\hline & & & $\begin{array}{l}\text { Physical-Chemical } \\
\text { (coagulation/ } \\
\text { flocculation) }\end{array}$ & \\
\hline & & & $\begin{array}{l}\text { Physical } \\
\text { (sedimentation) }^{3} \\
\text { (reverse osmosis) }^{1} \\
\text { (microfiltration) }^{3}\end{array}$ & \\
\hline TSS & 770 & $\begin{array}{l}\leq 10 \mathrm{mg} / \mathrm{L}(80 \% \text { of } \\
\text { samples }) \text { Greece }(2011) \\
\leq 35 \mathrm{mg} / \mathrm{L} \text { Spain }(2007) \\
\leq 5 \mathrm{mg} / \mathrm{L} \text { USEPA }(2012) \\
\leq 30 \mathrm{mg} / \mathrm{L} \text { USEPA }(2012)\end{array}$ & $\begin{array}{l}\text { Physical } \\
\text { (sedimentation) }^{2} \\
\text { (reverse osmosis, }^{2} \\
\text { Physical-Chemical } \\
\text { (coagulation and } \\
\text { flocculation) }{ }^{2} \text {, } \\
\text { Biological } \\
\text { (activated sludge) }^{2}\end{array}$ & $\begin{array}{l}\text { Decree } 1620 \text { Spain } \\
\text { (2007) and USEPA } \\
\text { (2012) }\end{array}$ \\
\hline Turbidity & 64.9 & $\begin{array}{l}\text { Turbidity }<5 \text { (ABNT, 2007) } \\
\text { Turbidity }<1 \text { NTU } \\
\text { Spain, }(2007) \\
\text { Turbidity } \leq 2 \text { NTU Greece } \\
\text { (2011) }\end{array}$ & $\begin{array}{l}\text { Physical } \\
\text { (Filtration) } \\
\text { Physical Chemical } \\
\text { (photo-oxidation with } \\
\left.\text { the addition of } \mathrm{H}_{2} \mathrm{O}_{2}\right)^{4}\end{array}$ & ABNT (2007) \\
\hline $\mathrm{pH}$ & $5.5-8.5$ & $\begin{array}{l}6-9 \text { USEPA }(2012) \\
6.5-8.4 \text { Spain }(2007) \\
6.5-8.5 \text { Greece }(2011) 6 \\
-8 \\
\text { ABNT }(2007)\end{array}$ & $\mathrm{pH}$ correction & $\begin{array}{l}80 \% \text { of samples meet } \\
\text { USEPA requirements } \\
\text { (2012) and JMD } \\
\text { (Greece, 2011), while } \\
70 \% \text { meet } \\
\text { requirements of Spain } \\
\text { (2007) and } 60 \% \text { meet } \\
\text { Brazilian requirements } \\
\text { (1997). }\end{array}$ \\
\hline $\begin{array}{l}\text { Thermot } \\
\text { coliform }\end{array}$ & 1000 & $\begin{array}{l}\text { T.C. }<200 \text { NPM } / 100 \mathrm{~mL} \\
(\text { ABNT, 1997) T.C. }<200 / \\
100 \mathrm{~mL} \text { USEPA }(2012)\end{array}$ & $\begin{array}{l}\text { Physical } \\
\text { (Reverse osmosis and } \\
\text { disinfection through } \\
\text { ultraviolet) }{ }^{3}\end{array}$ & $\begin{array}{l}\text { ABNT (2007) and } \\
\text { USEPA (2012) }\end{array}$ \\
\hline
\end{tabular}

1 Cristóvão et al. (2014); 2 Cristóvão et al. (2015); 3 Queiroz et al. (2013); 4 Luiz et al. (2011).

Source: USEPA (2012); Greece (2011); Spain (2007); ABNT (1997). 
Regarding turbidity, this parameter is directly related to the concentration of the suspended solids in the water; therefore, when suspended solids are removed, this parameter is also reduced.

The $\mathrm{pH}$ was between 5.5 and 8.5, close to the requirements of the EPA (USEPA, 2012) and Greek regulations (Greece, 2011) that require values between 6 and 9; and of Spanish requirements, which recommend $\mathrm{pH}$ between 6.5 and 8.4 (Spain, 2007) and of the Brazilian standard, between 6-8 (Brazil, 1997) (Table 3). It was determined that the pH parameter should be evaluated after applying treatment to remove or decrease the concentration of the previously presented parameters. The analyses of this study indicate that there may be minimal need for adjustment in this parameter, since it is close to the range of values presented by the regulations (Table 3).

Considering the characteristics of the effluents from Point A (the washing cylinder and evisceration stages), Point B (from health barriers (process employee hygiene) and washing of monoblocs, floors and equipments) and Point $\mathrm{C}$ (final effluent), reuse is recommended after treatment as specified in Figure 2. The effluents of Point B can be recycled after simple treatment to remove suspended solids and to disinfect.

To treat the effluent from the washing cylinder and evisceration stages aiming reuse, it is therefore necessary to remove organic matter and solids, common in effluents which contain blood, fish remains and viscera. The effluent must also be disinfected before it may be used for disinfection of drinking water in sanitary vessels, garden watering, in the sanitary barrier, in the washing of the floors (internal and external to the industry) as well as re-insertion into the productive process.

Due to the high organic load, if the final effluent undergoes treatments such as sedimentation/flotation, coagulation/flocculation, activated sludge, filtration, reverse osmosis and UV disinfection, it will reach drinking-water quality according to the European Directive 98/83/EC (Directiva..., 1998), as in the study by Cristóvão et al. (2015). This result was also found not only in fish industries, but also in poultry processing, studied by Luiz et al. (2011) where the effluent reached the quality of potable water, according to the Brazilian standard (Normative 2914/2011, Brazil, 2011), after treating the secondary effluent with pre-filtration followed by the addition of $\mathrm{H}_{2} \mathrm{O}_{2}$ and UV radiation (AOP $\mathrm{H}_{2} \mathrm{O}_{2} / \mathrm{UV}$ ).

Studies show that even the most concentrated effluents, when treated, can achieve water potability standards and can be applied to the same uses as fresh water, were it not for the restrictions of application and acceptance of this practice in the food industry. The direct recycling and reuse of effluent of the food preparation, handling and packaging processes are more restricted due to the industry's own strict cleaning- and hygiene requirements (Chowdhury et al., 2010), and there is little public acceptance due to the lack of knowledge regarding the benefits and safety of recycled water (Alcalde-Sanz and Gawlik, 2014).

Although Brazilian legislation allows only the use of drinking water in procedures that have contact with food in the industries (Brasil, 2011), there are international organizations such as Codex Alimenarius $(1999 ; 2001)$ that, in addition to recognizing, encourage the use of techniques of direct and indirect reuse in food industries, as long as these do not pose risks to the health of the manipulators and consumers, or to the environment or the integrity of the product. In this context, the objective of this study was to identify the possibility of minimizing water use and to evaluate the reuse potential of effluent from the fish-processing industry. 

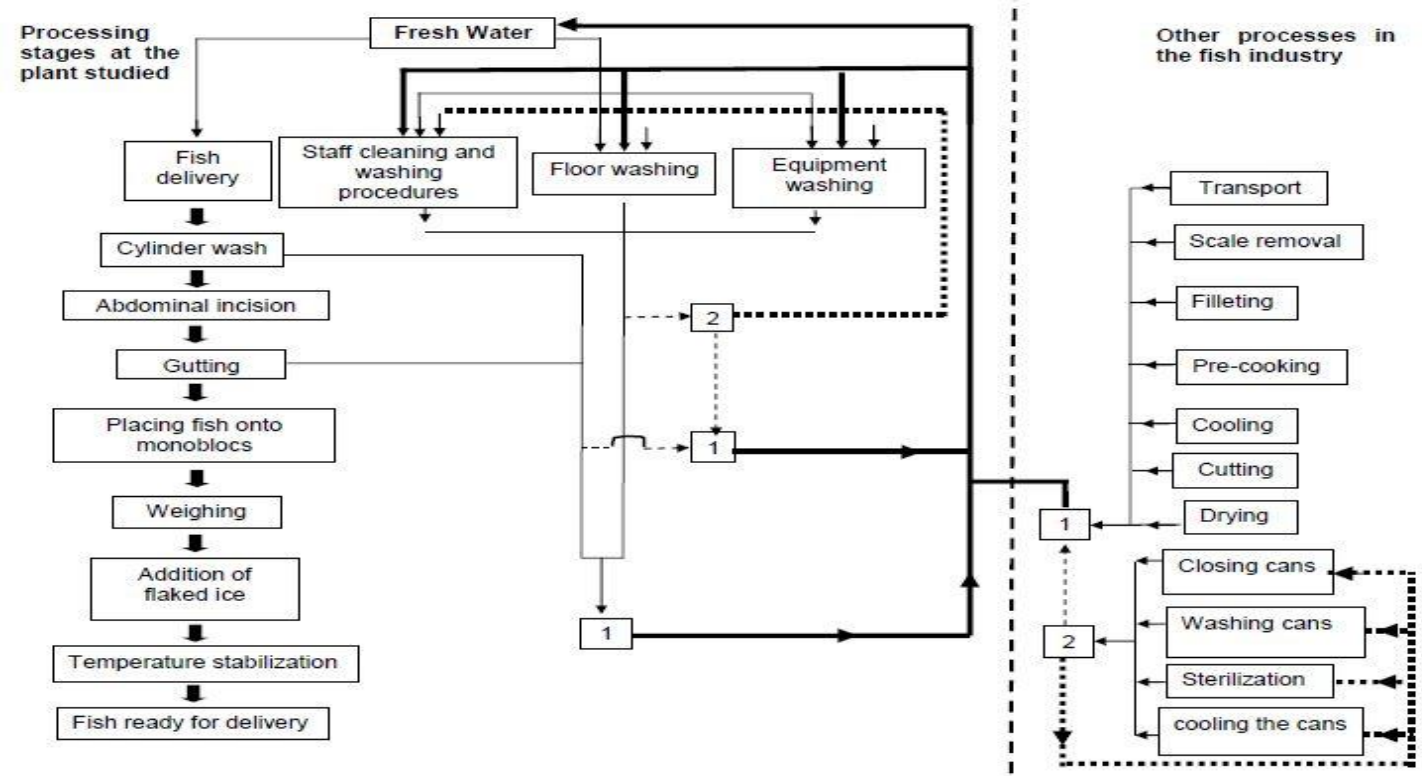

Figure 2. Potential recycling and reuse of effluents in the fish processing industry.

Note: 1- The dissolved, suspended and sedimented solids of organic matter should be removed followed by disinfection for reuse in industrial processes; 2 - Suspended solids must be removed and disinfection carried out to recycle the effluent.

\section{CONCLUSIONS}

Considering the potential of reuse or recycling of generated effluents, the characterization of the effluent verified that parameter BOD does not comply with any of the norms consulted regarding industrial reuse. For TSSs, the resulting concentration exceeds that recommended by the EPA, the Spanish Decree and Greek Regulation regarding turbidity and coliforms. Further, it does not comply with Brazilian or US regulations.

However, if the effluent is treated to mitigate its organic and solid content and microbiological characteristics, reuse is possible. The effluent may be pre-treated with membrane filtration and UV disinfection, and later with nano-filtration followed by reverse osmosis. The resulting effluent will be drinking-water quality. Regarding BOD, studies show that a treatment with the use of microalgae and coagulation / flocculation, followed by sedimentation and microfiltration, may allow the effluent to meet the requirements of Decree 1620, of Spain, of the EPA, Greece and Brazil.

Regarding TSS, the effluent can meet North American and Spanish requirements if it is submitted to activated sludge treatments followed by osmosis. Regarding $\mathrm{pH}$, this study indicates that there may be a minimal need for adjustment in this parameter, since it is close to the range of values presented by the studied norm.

\section{ACKNOWLEDGMENTS}

The authors thank the Conselho Nacional de Desenvolvimento Científico e Tecnológico (CNPQ) for the project financing (Process: 407728 / 2012-0) and for the productivity grant (Process 312697 / 2014-7). The Coordenação de Aperfeiçoamento de Pessoal de Nível Superior (CAPES), for the scholarship awarded (Process: 312697 / 2014-7). 


\section{REFERENCES}

ASSOCIAÇÃO BRASILEIRA DE NORMAS TÉCNICAS - ABNT. NBR 13969: tanques sépticos - unidades de tratamento complementar e disposição final dos efluentes- projeto, construção e operação. Rio de Janeiro, 1997.

ACHOUR, M.; KHELIFI, O.; BOUAZIZI, I.; HAMDI, M. Design of an integrated bioprocess for the treatment of tuna processing liquid effluents. Process Biochemistry, v. 35, p. 1013-1017, 2000. https://doi.org/10.1016/S0032-9592(00)00133-3

ALCALDE-SANZ, L.; GAWLIK, B. M. Water Reuse in Europe: Relevant guidelines, needs for and barriers to innovation. 2014. Disponível em: https://ec.europa.eu/jrc. Access in: 10 out. 2015.

ALEXANDRE, V. M. F.; VALENTE, A. M.; CAMMAROTA, M. C.; FREIRE, D. M. G. Performance of anaerobic bioreactor treating fish-processing plant wastewater prehydrolyzed with a solid enzyme pool. Renewable Energy, v. 36, p. 3439-3444, 2011. https://doi.org/10.1016/j.renene.2011.05.024

AMERICAN PUBLIC HEALTH ASSOCIATION APHA. Standard methods for the examination of water and wastewater. $20^{\text {th }}$ ed. Washington D.C, 2005.

ARTIGA, P.; GARCÍA-TORIELLO, G.; MÉNDEZ, R.; GARRIDO, J. M. Use of a hybrid membrane bioreactor for the treatment of saline wastewater from a fish canning factory. Desalination, v. 221, p. 518-525, 2008. https://doi.org/10.1016/j.desal.2007.01.112

AYERS, R. S.; WESTCOT, D. W. Water quality for agriculture. Rome: FAO, 1985. (Irrigation and Drainage paper, 29).

BIXIO, D.; WINTGENS, T. Water reuse system management manual - AQUAREC. Luxembourg: EC, 2006.

BRASIL. Ministério da Saúde. Portaria no 2.914, de 12 de dezembro de 2011. Dispõe sobre os procedimentos de controle e de vigilância da qualidade da água para consumo humano e seu padrão de potabilidade. Diário Oficial [da] União, Brasília, 26 dez. 2011.

BRASIL. Presidência da República. Casa Civil. Decreto no 30.691, de 29 de março de 1952. Aprova o novo Regulamento da Inspeção Industrial e Sanitária de Produtos de Origem Animal. Diário Oficial [da] União, Brasília, 07 jul. 1952. BRASIL. Secretaria de Defesa Agropecuária. Portaria n ${ }^{\circ}$ 210, de 10 de novembro de 1998. Diário Oficial [da] União, Brasília, 05 mar. 1999. Seção I, p. 17-22.

BRASIL. Secretaria Nacional de Vigilância Sanitária. Portaria SVS/MS nº 326, de 30 de Julho de 1997. Diário Oficial [da] União, Brasília, 01 ago. 1997

CHOWDHURY, P.; VIRARAGHAVAN, T.; SRINIVASAN, A. Biological treatment processes for fish processing wastewater - A review. Bioresource Technology, v. 101, p. 439-449, 2010. https://doi.org/10.1016/j.biortech.2009.08.065

CODEX ALIMENTARIUS COMMISSION. Codex Committee on Food Hygiene. Thirtyfourth Session: proposed draft guidelines for the hygienic reuse of processing water in food plants. Bangkok, 8-13 October 2001.

CODEX ALIMENTARIUS COMMISSION. Codex Committee on Food Hygiene. Thirtysecond Session: discussion paper on proposed draft guidelines for the hygienic reuse of processing water in food plants. Washington, D.C., November 29-December 4, 1999. 
CONSELHO NACIONAL DE METROLOGIA, NORMALIZAÇÃO E QUALIDADE INDUSTRIAL - CONMETRO (Brasil). Resolução n 01/80, de 17 de março de 1980 Brasília, 1980.

CONSELHO NACIONAL DE RECURSOS HÍDRICOS - CNRH (Brasil). Resolução n 54, de 28 de nov. de 2005. Estabelece modalidades, diretrizes e critérios gerais para a prática de reúso direto não potável de água, e dá outras providências. Diário Oficial [da] União, Brasília, 09 mar. 2006.

CRISTÓVÃO, R.; BOTElHO, C. M.; MARTINS, R. J. E.; LOUREIRO, J. M.; BOAVENTURA, R. A. R. Primary treatment optimization of a fish canning wastewater from a Portuguese plant. Water Resources and Industry, v. 6, p. 51-63, 2014. https://doi.org/10.1016/j.wri.2014.07.002

CRISTÓVÃO, R.; BOTELHO, C. M.; MARTINS, R. J. E.; LOUREIRO, J. M.; BOAVENTURA, R. A. R. Fish canning industry wastewater treatment for water reuse e a case study. Journal of Cleaner Production, v. 87, p. 603-612, 2015. https://doi.org/10.1016/j.jclepro.2014.10.076

DIRECTIVA 98/83/CE do Conselho de 3 de novembro de 1998 relativa à qualidade da água destinada ao consumo humano. Jornal Oficial das Comunidades Europeias, $02 \mathrm{dez}$. 1998. p. 330/32-54.-

GHALY, A. E.; RAMAKRISHNAN, V. V.; BROOKS, M. S.; BUDGE, S. M.; DAVE, D. Fish Processing Wastes as a Potential Source of Proteins, Amino Acids and Oils: A Critical Review. Journal of Microbial \& Biochemical Technology, v. 5, p. 107-129, 2013. http://dx.doi.org/10.4172/1948-5948.1000110

GREECE. Joint Ministerial Decree (JMD) 145116/2011: definition of measures, conditions and procedure for wastewater reuse. Greek Government Gazette, n. 354B, 8 mar. 2011.

HERPANDI, N. H. et al. The tuna fishing industry: a new outlook on fish protein hydrolysates. Comprehensive Reviewsin Food Science and Food Safety, v. 10, p.195-207, 2011. http://dx.doi.org/10.1111/j.1541-4337.2011.00155.x

INSTITUTO BRASILEIRO DE GEOGRAFIA E ESTATÍSTICA - IBGE. Pesquisa da Pecuária Municipal 2013-2014. PPM 2014: rebanho bovino alcança 212,3 milhões de cabeças. 2014. Disponível em: http://shorturl.at/couU3. Acesso em: out. 2015.

JEMLI, M.; KARRAY, F.; FEKI, F.; LOUKIL, S; MHIRI, N; ALOUI, F. et al. Biological treatment of fish processing wastewater: A case 2 study from Sfax City (Southeastern Tunisia). Journal of Environmental Sciences, v. 30, p. 102-112, 2015. https://doi.org/10.1016/j.jes.2014.11.002

LIMA, L. K. F.; PONSANO, E. H. G.; PINTO, M. F. Cultivation of Rubrivivax gelatinosus in fish industrial effluent for depollution and biomassa production. World Journal Microbiol Biotechnol. Vol. 27, p. 2553-2558, 2011.

LUIZ, D. B.; SILVA, G. S.; VAZ, E. A. C.; JOSÉ, H. J.; MOREIRA, R. F. P. M. Evaluation of hybrid treatments to produce high quality reuse water. Water Science \& Technology, v. 63.9, p. 2046-2051, 2011. http://dx.doi.org/10.2166/wst.2011.468

MATSUMURA, E. M.; MIERZWA, J. C. Water conservation and reuse in poultry processing plant-A case study. Resources, Conservation and Recycling, v. 52, p. 835-842, 2008. https://doi.org/10.1016/j.resconrec.2007.10.002 
MAVROV, V.; BÉLIÈRES, E. Reduction of water consumption and wastewater quantities in the food industry by water recycling using membrane processes. Desalination, v. 131, p. 75-86, 2000. https://doi.org/10.1016/S0011-9164(00)90008-0

MUTHUKUMARAN, S.; BASKARAN, K. Organic and nutrient reduction in a fish processing facility- A case study. International Biodeterioration e Biodegradation, v. 85, p. 563570, 2013. https://doi.org/10.1016/j.ibiod.2013.03.023

ORGANIZATION FOR ECONOMIC CO-OPERATION AND DEVELOPMENT - OCDE. Estatísticas tributárias na América Latina e no Caribe 1990-2013. Relatório (quarta edição). 2013. Available at: http://www.latameconomy.org/en/revenue-statistics. Access: 25 Oct. 2015.

QUEIROZ, M. I.; HORNES, M. O.; SILVA-MANETTI, A. G.; JACOBE-LOPES, E. Fish processing wastewater as a platform of the microalgal biorefineries. Biosystems $\begin{array}{lllll}\text { Engineering, } & \text { v. } & 115, & \text { p. } & 195-202,\end{array}$ https://doi.org/10.1016/j.biosystemseng.2012.12.013

SILVA, A. J. et al. Utilization of tilapia processing waste for the production offish protein hydrolysatej. Animal feed science and technology, v. 196, n. 11, p. 96-106, 2014. https://doi.org/10.1016/j.anifeedsci.2014.06.010

SPAIN. Ministerio de la Presidencia. Real Decreto 1620/2007, de 7 diciembre, por el que se establece el regímen jurídico de la reutilización de las aguas depuradas. Boletín Oficial [del] Estado, Madrid, n. 294, p. 50639-50661, 8 dic. 2007.

UNITED STATES. Environmental Protection Agency - USEPA. Guidelines for Water Reuse. Washington, D. C., 2004.

UNITED STATES. Environmental Protection Agency - USEPA. Guidelines for Water Reuse. Washington, D. C., 2012.VALENT, A. M.; ALEXANDRE, V. M.; CAMMAROTA, M. C.; FREIRE, D. M. G. Pré-hidrólise enzimática da gordura de efluente da indústria de pescado objetivando o aumento da produção de metano. Ciência e Tecnologia Alimentar, v. 30, n. 2, p. 483-488, 2010.

WORLD HEALTH ORGANIZATION - WHO. Guidelines for the safe use of wastewater, excreta and greywater. Washington, D. C., 2006. 